\title{
Federalism and constitutional asymmetry
}

As Taras notes, 'Establishing a constitutional framework that sets out the political rules of the game and the institutions that allocate values in society is the most daunting challenge for a new regime'. ${ }^{1}$ For Maravall and di Tella, two features of constitutionalism are particularly important. First, constitutions seek to define, 'the future substance as well as the form of politics by placing certain political, social and economic, rights beyond the reach of democratic uncertainty'. And second, 'to make such assurances credible, constitutions bind not just their drafters, but future generations'.2

We also need to distinguish between 'those constitutions that result from a process of extensive compromise and widespread acceptance', and those 'that are enacted by a victorious majority over the objection of minorities' ${ }^{3}$ In the former we are far more likely to achieve stable and long lasting constitutions, whilst in the latter case, unstable and short lived constitutions are the norm.

In Russia, as we have seen, there was little evidence of consensus and compromise in the drafting of its Constitution. Instead, the foundations of Russian constitutionalism were forged out of conflict and coercion, and the president's Constitution was largely imposed on a weak and highly divided society, still reeling from the shock of the violent dissolution of the Russian parliament. Moreover, as Stepan notes, 'the parliament never discussed the version of the constitution that was submitted to the voters for ratification, and thus the chance for constitution-making to play a focal role in building consensus for democratic state power was lost'. ${ }^{4}$

\section{The Russian constitution}

The 1992 victory of the republics over the federal authorities appeared to come to an end with Yeltsin's dissolution of the Russian parliament in October 1993 and the adoption of his Presidential Constitution in Decem- 
ber 1993. The dramatic assault by Russian troops on the Russian parliament and the arrest of Khasbulatov, and the other leading parliamentarians, followed by Yeltsin's decrees abolishing the institutions of the local assemblies (soviets), frightened the regions into submission. As Zverev notes, 'tax returns hitherto withheld by the regions began pouring into Moscow and talk of separate republics in the Urals, Siberia and the Far East temporarily ceased, ${ }^{5}$

The new Constitution reasserted the authority of the federal authorities, the integrity and inviolability of the Federation, the supremacy of the Constitution and federal laws throughout the territory of the country, the creation of a single unified system of executive power, and a single economic space. There was also a notable absence of the right of the 'subjects' to secede from the Federation (article 4) or to have their own republican citizenship. And to the dismay of the republics the text of the Federal Treaty was not incorporated into the Constitution, and the superiority of the Constitution over the Federal Treaty was set out in section two. Moreover, the Constitution proclaimed that all subjects of the federation were equal (article 5) thus rejecting the special privileges which had been granted to the republics in March 1992.

\section{The distribution of powers}

As we noted in chapter 1 there are wide variations in the way in which power is distributed in federations. In most federal constitutions the federal authorities and federal subjects are each granted exclusive powers over specific policy areas. However, often there is also the need for a list of 'concurrent powers' to be specified which come under the joint jurisdiction of the federal government and federal subjects. Russia's Constitution favours the federal authorities over the subjects. Thus, article 71 grants the federal government exclusive powers over a broad range of national policies (including the national economy, federal budget, federal taxes and duties; foreign and defence affairs), and article 72 lists a number of powers which are to be shared between the federal authorities and the federal subjects (see appendices 3.1 and 3.2). However, as we noted in chapter 1, unlike in the Federal Treaty, no exclusive powers were delegated to the federal subjects. Instead, the subjects are granted only 'residual powers' (article 73), that is, powers over those relatively few policy areas not provided for in articles 71 and 72.

Another important article in the Constitution is the so called 'flexibility clause' (article 78) which allows the centre to transfer 'the implementation of some of its powers' to the federal subjects and vice versa. ${ }^{6}$ As Lapidus and Walker rightly note, this left 'open the possibility of bilateral agreements between Moscow and the subjects and the further development of an asymmetrical federation', which we discuss below. ${ }^{7}$ 


\section{Popular support for the Constitution}

There was however, one major drawback to Yeltsin's supposed constitutional victory. Although the Constitution was supported by 58.4 per cent of the voters nationwide (according to official statistics), it was rejected by a majority of voters in sixteen regions, and in eight of the twenty-one republics. Additionally, in eleven regions and six republics the Constitution failed to be ratified, as turnout was below the required 50 per cent. ${ }^{8}$ And the Constitution was boycotted altogether in Chechnya. Surely, as we have noted, an essential attribute of any democratic federation is the voluntary membership of its subjects. But in Russia the Constitution failed to be ratified in forty-two of the eighty-nine subjects. Moreover, the legitimacy of the Constitution was also weakened by doubts over the validity of the officially declared turnout of 54.8 per cent. According to some estimates the actual turnout was well below the required 50 per cent and actually lay somewhere between 38 and 43 per cent. ${ }^{9}$

Such doubts over the legitimacy of the Constitution has fundamentally weakened the powers and authority of the federal government in its relations with the federal subjects, particularly in those regions where the Constitution failed to be ratified. Thus, Yeltsin's victory in 1993 was like Gorbachev's before him, a pyrrhic one. Devoid of any real legitimacy, the Constitution was soon open to creative interpretation, indifference, and even outright abuse, by regional political elites, who were able to bolster their 'patrimonial' regimes with claims for economic and political sovereignty.

There was no democratic revolution or people's revolution in Russia as there had been in Eastern Europe in 1989, and 'nomenklatura continuity' was the norm in the regions, as former communist elites took power under the new banner of national sovereignty. Moreover, as scholars of federalism stress, for a democratic federation to function we need not only federal structures and institutions but a democratic political culture, an agreement by all signatories to abide by the democratic and constitutional rules of the game. In Russia all of the federal structures were put in place by the Constitution but in the absence of a federal democratic culture. Thus, as we noted in chapter 1 , a federation was formed without federalism.

\section{The formation of a bicameral national parliament}

As we noted in chapter 1 , one of the key structural prerequisites of federal states is the institutional representation of regions in policy making at the federal level. To this end federal states have created bicameral national parliaments with an upper chamber especially designed to accommodate regional interests. In Russia, the Constitution called for the creation of a 
bicameral national parliament with an upper house comprising two representatives from each of Russia's eighty-nine subjects.

There are considerable variations in the powers of upper chambers, the methods by which their member are elected, their relations with other federal and regional bodies, and the equality of representation within them. As Watts notes, members of upper chambers may be selected by the following methods: (1) direct election (e.g., USA, Austalia, Switzerland), (2) indirect election from the subject assemblies (e.g., Austria, India), (3) ex officio appointment (e.g., of Lander cabinets in Germany), (4) through direct appointment by federal bodies (e.g., the federal Prime Minister in Canada), (5) by mixed systems of indirect/direct elections and appointments (e.g., Malaysia, Belgium, Spain). ${ }^{10}$

According to the Russian Constitution the Federation Council consists of, 'two representatives from each component of the Russian Federation; one each from the representative and executive bodies of state power (article 95). However, the Constitution did not stipulate the precise method by which members were to be chosen. In 1993 the first Council was elected via national elections. However, the method of choosing members was changed by Yeltsin in 1995 and again by Putin in 2000 (see chapter 8). From 1996 until 2000 the heads of the legislative and executive branches of government in each region were granted ex officio membership of the Council. Thus, during this period, the Council was indirectly elected, and its composition was decided by whoever held the post of chair of a regional assembly or head of a regional administration. Members of the Council could retain their seats as long as they held their regional posts. Therefore, as Teague notes, 'Since electoral laws varied from region to region, [this] also meant that the composition of the upper chamber was effectively determined not by federal norms but by regional ones'. Thus, included in the upper chamber were a number of republican presidents who had come to power through uncontested and/or unfair elections (e.g., President Shaimiev of Tatarstan, President Rakhimov of Bashkortostan). Also by including regional executives in its ranks the upper chamber violated the democratic principle of the separation of powers.

In 2000 President Putin radically changed the method by which members of the Federation Council are 'elected', which has fundamentally weakend its authority. No longer do heads of regional administrations and chairs of regional assemblies have ex officio membership; instead each sends a deputy to represent them in the Council. We shall discuss Putin's reforms further in chapter 8.

The changes enacted in 1995 were deliberately designed to give Yeltsin control over the lower house of the parliament (the Duma). As the Federation Council has the powers to veto legislation of the lower house, Yeltsin, by controlling the membership of the upper house, was able to 
gain significant leverage over the work of the Duma. Thus, as Kempton notes, 'Although most republican leaders were popularly elected, the governors of most of the regions were handpicked by Yeltsin and were subject to removal by Yeltsin'. ${ }^{11}$ The upper chamber is also charged with approving the President's nominations for the top posts in the judiciary and procuracy. Thus, by packing the Council with his appointees, Yeltsin also gained control over these bodies. Only after Yeltsin reluctantly relinquished his powers of appointment over regional governors, and gave the go ahead for nationwide gubernatorial elections (conducted over the period 1995-97) did he begin to lose control over the membership and work of the Council (see chapter 6).

Political asymmetry can be found in the over-representation of some regions in the upper chambers of federal parliaments. In Russia all eightynine federal subjects have equal representation in the Federation Council even although there are massive variations in the size of their populations. Thus, Moscow city and the Yevenk autonomous oktug (AO) both have two 'senators' even although Moscow's population is 443 times larger than that of Yevenk. However, as Watts observes, equality of representation in the federal second chamber (also found in the USA, and Australia), is not, in fact, the norm. In most federations representation is weighted in favour of 'smaller regional units' and/or 'significant minorities'. ${ }^{2}$ But, as Stepan warns us, 'the greater the representation of the less populous states (and therefore the underrepresentation of the more populous states), the greater the demos-constraining potential of the upper house will $\mathrm{be}^{\prime} .^{13}$ One way of ameliorating such inequalities is to vary the number of members elected from each federal subject. Thus, for example, in Germany there are lander having between 3-6 block votes in the upper chamber depending on the size of their populations, whilst in India representation of the states varies from as much as 12 to $86 .{ }^{14}$

There are also considerable variations in the powers granted to upper chambers but these will usually include; 'confirmation of federal judges, approval of the federal budget, changes in tax laws affecting the components, territorial changes, education policy, language policy and cultural policy ${ }^{\prime 15}$ Upper chambers also have a key role in reviewing legislation so as to ensure the interests of the regions are promoted and protected.

Stepan also argues that, 'the greater the competence of the territorial house, the more the demos - which is represented on a one person-one vote basis in the lower house - is constrained'. Thus, for example, in Brazil senators representing just 13 per cent of the total electorate have no restrictions placed on the policy areas they can vote on and indeed there are twelve areas where the upper chamber has been granted exclusive competence. ${ }^{16}$ The 'German, Spanish and Indian systems are less demosconstraining, because their upper houses are less unrepresentative and less powerful'. ${ }^{17}$ 
From a comparative perspective the Russian Federation Council is a relatively weak federal institution, which has been dominated for much of its existence by the presidency. It is the lower house, the state Duma, which is the law-making chamber. The upper chamber has the more limited power to approve or reject the legislation of the lower house. However, a veto by the Federation Council can be overturned by a twothirds majority in the lower house Duma. The President also has the power to veto the legislation of both houses which can only be overturned by a vote of two-thirds of the members of both chambers.

The authority of the Federation Council is also weakened by the fact that most of its members have often been too preoccupied with their duties in the regions to attend its sessions. Indeed, often it has been difficult to achieve a quorum and the Council has had to resort to postal voting. Also according to article 105, legislation of the Duma 'is deemed to have been approved by the Federation Council' if it has not been examined by the upper chamber within 14 days. Up until 2002 the Council met for only a few days each month, ${ }^{18}$ hardly sufficient time to carry out its duties. Thus, many laws of the Duma have been approved without the scrutiny of the Council. Another sign of the weakness of the Federation Council is its failure to use its right of legislative initiative. Thus, 'only about 7 per cent of draft laws prepared by the upper chamber and its members in 1994-98 passed all stages of the legislative process and were adopted as federal laws'. ${ }^{19}$

Nonetheless, the Council has acted as a forum for the airing of regional interests in the centre, and regional elites have been able to defend their rights and privileges via the Council. The Council also successfully thwarted the adoption of a key law which would have tightened up centre-periphery relations and reduced the powers of the regions vis-àvis the centre.

In the late 1990s the Council also played a more prominent role in drawing up the federal budget. And once Yeltsin lost his control over appointments to the Council his ability to influence the courts and procuracy was also weakened. Thus, for example, in 1999 the Council refused to approve Yeltsin's repeated calls for the Procurator General, Skuratov, to resign. ${ }^{20}$

\section{Constititutions of the republics}

Regional elites have been able to use inherent contradictions in the Russian Constitution to their own advantage. Thus, for example, whilst the Constitution declares that all subjects are equal, in fact there are three distinct classifications of 'federal subject' in the document. First, the twenty-one ethnically based republics which are classified as nationalstate formations. Second, krai and oblasts, which are classified as 
administrative-territorial formations; and third, autonomous oblasts and autonomous okrugs defined as national-territorial formations. ${ }^{21}$ Only the republics are defined as 'states' with the right to their own constitutions, languages, flags, hymns and other trappings of statehood.

There was also a great deal of ambiguity over the status of the Federal Treaty. Thus, for example, article 11 of the Constitution states that centre-periphery relations are to be determined 'by the Federal Treaty and other treaties' which suggests that the Federal Treaty and the Constitution are both still valid - a position defended by many of the republics who refused to relinquish the powers given to them in March 1992. As we discuss below, this article (alongside article 78) legitimised the creation of bilateral treaties between the national government and the federal subjects, increasing the levels of constitutional asymmetry in the federation.

It was not long before a number of those republics whose citizens had rejected the constitution declared that the Federal Constitution was not valid in their territories, and that their own constitutions were to take precedence. Those constitutions ratified between the signing of the Federal Treaty in March 1992 and the ratification of the Russian Constitution on December, 121993 (Chuvashiya, Sakha, Chechnya, Tatarstan and Tyva), were among the most radical, granting the republics rights of selfdetermination, sovereignty and secession. Indeed, a number of republics (Tatarstan, Bashkortostan, Sakha, Tyva, Ingushetiya and Buryatiya) went so far in their rejection of the Federal Constitution that their relations with the centre were much more typical of those in a confederation than a federation.

A majority of Russia's twenty-one republics adopted constitutions which violate the Russian Constitution (contravening articles 4 and 15 of the Russian Constitution). ${ }^{22}$ And Constitutional asymmetry created political asymmetry. Before long there was a multitude of differing political systems operating in the Russian Federation including different types of political regime (presidential or parliamentary); electoral systems (proportional, majoritarian or mixed); and party systems. Across the federation we could soon detect a political spectrum running from partial democratisation at one end to delegative democracies and outright dictatorships at the other. However, one universal rule could be detected - the greater the autonomy granted to a federal subject the greater the level of authoritarianism. As we discuss in chapter 9, it is in the ethnic republics, granted most autonomy by the Constitution, that we find most violations, and also the highest levels of authoritarianism.

\section{Rights of sovereignty, self-determination and secession}

In this section I analyse the constitutions as first promulgated in the early 1990s before the substantial revisions which have taken place since the 
inauguration of President Putin in 2000. Putin's reform of the federal system is discussed in chapter 8 .

As we noted above, the Constitution unlike the Federal Treaty before it, does not grant the republics the rights of sovereignty and secession. Article 4 (1) of the Russian Constitution states that, 'The sovereignty of the Russian Federation extends to the whole of its territory', and article 4(3) declares that, 'The Russian Federation ensures the integrity and inviolability of its territory'. Nonetheless, 19 of the 21 republics (with the exception of Ingushetiya and Kalmykiya) declared their state sovereignty, and by implication the right of secession. Thus, for example, article 1 of the Constitution of Tyva stated that as a sovereign state Tyva is a member of the Russian Federation on the basis of a Federal Treaty and as such Tyva has the right to self-determination and the right to secede from the Russian Federation. Article 61 of Tatarstan's Constitution declared, 'The Republic of Tatarstan shall be a Sovereign State, a subject of international law, associated with the Russian federation on the basis of a treaty and the mutual delegation of powers'. Likewise, article 5 of Bashkortostan's Constitution noted that:

Bashkortostan joined the Russian Federation on a voluntary and equal basis. Relations between the Republic of Bashkortostan and the Russian Federation are determined by the Treaty on the basis of intergovernmental relations between the Russian Federation and Bashkortostan, and other bilateral treaties and agreements.

The Constitution of Chechnya goes even further, failing to even note that it is actually a subject of the Russian Federation, instead it proclaims that Chechnya is an independent sovereign state and a full and equal member of the world community of states.

In the Constitution of North Osetiya-Alaniya it proclaims that the Republic is a 'state, voluntarily entering into the composition of the Russian Federation'. Other constitutions stressed that their relations with the Russian Federation were based on the free delegation of their powers to the federation (Buryatiya, Bashkortostan, Sakha). The state sovereignty of republics is also often acknowledged in their friendship treaties with other subjects of the federation. Thus, the preamble to the treaty between Bashkortostan and Chuvashiya on 24 May 1994 recognized the mutual sovereignty of each republic. ${ }^{23}$

Further provisions guarantee the supremacy of the Federal Constitution in the Federation. Thus, article 4(2) states that, 'the constitution of the Russian Federation and federal laws are paramount throughout the territory of the federation' and article 15(1) declares that: 'The Constitution of the Russian Federation has supreme legal force and is direct acting and applies throughout the territory of the Russian Federation. Laws and other legal enactments adopted in the Russian Federation must not contradict the Constitution'. 
But these provisions are simply ignored in a number of republican constitutions which defiantly proclaimed the supremacy of their constitutions over the Federal Constitution (e.g., article 7 of the Constitution of Sakha, article 15 of Bashkortostan, article 1 of Tyva, article 1 of Dagestan, and article 7 of Komi). ${ }^{24}$ Article 1 of Tyva's Constitution stated that at times of political or state crisis in the republic, the Republic's Constitution was to take priority over federal laws and all powers were to pass to the parliament (the Supreme Khural), president and government. Similarly, article 1 of Bashkortostan's Constitution declared that, 'The Republic of Bashkortostan has supreme authority on its territory, independently defining and conducting domestic and foreign policies, adopting the Bashkortostan Constitution and laws, which have supremacy on the entire territory'. This article went on to state, that the only federal laws that must be enforced in Bashkortostan are those that were 'voluntarily granted by Bashkortostan to the purview of the Russian Federation'. Article 59 of the Constitution of Tatarstan proclaimed that, 'the laws of the Republic of Tatarstan shall enjoy supremacy over all its territory'. In the constitutions of Sakha (articles 58 and 70), Bashkortostan (article 95) and Komi (article 73) there were further provisions granting the republic authorities the right to suspend federal laws and acts which violated their constitutions.

\section{Unilateral expansion of powers}

A number of republic constitutions have also unilaterally taken jurisdiction over policy areas which according to article 71 come under the exclusive jurisdiction of the federal government. Thus, for example, the Constitution of Tyva granted the republic the right to decide issues of war and peace. Some constitutions allowed the republics to adopt laws about military service (Bashkortostan, Sakha, Tyva) and establish procedures for declaring a state of emergency in their territory (Buryatiya, Komi, Tyva, Bashkortostan, Kalmykiya, Kareliya, North Osetiya, Ingushetiya). Others gave themselves the exclusive right to engage in foreign relations and foreign trade, and to sign international treaties (Bashkortostan (article 88), Chechnya (article 62), Dagestan, Ingushetiya (article 54), Sakha (article 69), Tatarstan (article 89) ${ }^{25}$ Some republics (Tatarstan (article 8), Tyva (article 3), Sakha (article 6)) unilaterally declared their territories as nuclear free zones in violation of article 71, point ' $\mathrm{m}$ ' of the Russian Constitution which states that such questions fall squarely within the competence of federal authorities.

\section{Ownership of land and other natural resources}

In the Russian Constitution, in distinction from the Federal Treaty, it clearly states that the ownership, use and disposal of land and minerals come under the joint jurisdiction of the federal authorities and federal 
subjects (article 72). But only two republican constitutions (Komi and Kareliya) conformed in this respect. In particular, Sakha, Tatarstan, Bashkortostan, Tyva and Buryatiya, all declared that such natural resources belong to the republics. Article 10 of Bashkortostan's Constitution stated that the, 'earth, resources, natural wealth, and other resources on the territory of Bashkortostan are the property of its people. Questions about the ownership, use, and distribution of the land, resources, natural wealth, and other resources are determined by Bashkortostan legislation' ${ }^{26}$ And in violation of article 67 (points 1 and 2) of the federal Constitution, Sakha's Constitution (article 5) went so far as to declare, that even the 'air space, and continental shelf of the territory is the inalienable property of the citizens of the Republic'..$^{27}$

In a number of republic constitutions the right to private property is unconstitutionally prohibited in some areas. Thus, for example in Sakha, land and minerals may not be in private ownership. In the Constitution of Tyva it actually states that land is under state ownership. Other republics have used such provisions to try and prohibit or reverse privatisation programmes in their territories. Several republics also give themselves the right to decide questions regarding the federal budget. Thus, for example, the constitutions of Sakha and Bashkortostan noted that their legislative organs had the right to define the volume of payments to the federal budget - a provision that clearly contradicted article 71 of the Russian Constitution.

\section{Citizenship}

In the majority of republican constitutions it is stated that granting and terminating citizenship is based on republican laws. That is, such matters come under the exclusive jurisdiction of the republics. ${ }^{28}$ Thus, for example, article 19 of the constitution of Tatarstan stated that: 'The Republic of Tatarstan shall have its own citizenship. The reasons and procedures for acquiring and renouncing the citizenship of the Republic of Tatarstan shall be established by the law on citizenship of the Republic of Tatarstan. Citizens of the Republic of Tatarstan shall be admitted to have the citizenship of the Russian Federation'. Such powers over defining citizenship rights are in clear contradiction of article 6 of the Russian Constitution which states that, 'Citizenship of the Russian Federation is acquired and terminated in accordance with federal law', and also article 71 which clearly places citizenship under federal jurisdiction. ${ }^{29}$

\section{Powers over the courts}

All scholars of federalism agree that a necessary prerequisite for federalism is some form of adjudication between the levels of government. To 
this end federal states have created supreme courts which serve as the final adjudicator in relation to all laws, and constitutional courts which specialise in constitutional interpretation. ${ }^{30}$ Indeed, as Kempton notes, 'because of the importance that federalism gives to the judiciary it is sometimes derogatorily labelled "government by the judiciary"'. ${ }^{31}$ And in order to ensure the independence and impartiality of the courts it is now common practice for both the federal government and the federal subjects (usually through their representation in the upper chamber of the national parliament) to be given a voice in the appointment of the court's membership. Thus, for example, in the USA members of the Supreme Court, are appointed by the President, subject to the ratification of the upper chamber. In Germany the Bundesrat representing the Lander appoints half the members of the Constitutional Court, and the Bundestag the other half. In Spain the Constitutional Court is composed of 12 members, of whom 4 are elected by Congress, 4 by the Senate, 2 are appointed on the proposal of the Government Council, and 2 are appointed on the proposal of the General Council of Judicial Power. Whilst in Belgium, the members of the Court of Adjudication are simply elected by the multi-party Federal Assembly. ${ }^{32}$

\section{The Russian Constitutional Court}

In Russia members of the Constitutional Court and the Supreme Court are appointed by the President subject to ratification of the Federation Council. However, the Russian Constitutional Court is organised according to federal principles. And article $72(\mathrm{k})$ of the Russian Constitution puts personnel appointments of federal branches of the judiciary under the joint authority of the federal authorities and federal subjects. Nonetheless, in a number of regions such rights have been unilaterally transferred to the sole jurisdiction of the republics. Although fifty regional constitutions and charters outline the rights and duties of regional constitution courts only twelve regions have actually gone so far as to establish these bodies. ${ }^{33}$ In ten regions the governor/president nominates members of the courts and these nominees are then ratified by the parliaments. In Adygeya the three branches of government (judiciary, parliament and executive) each appoint three justices. In St Petersburg, small groups of regional legislators, the Council of Judges, and the governor nominate candidates which then go before the the regional assembly for ratification. ${ }^{34}$

\section{The procuracy}

The procuracy in distinction to that of the Constitutional Court is not a federal body. In the Russian Constitution it states that, 'The Russian Federation Procurator's Office is a single centralised system in which the 
lower level procurators are subordinate to higher-level procurators and to the procurator-general of the Russian Federation' (article 129(1)). And article 129(2) notes 'the Procurator general is appointed and released from office by the Federation Council on the submission of the President'. Article 129(3) states that, "The procurators of subjects of the Russian Federation are appointed by the procurator general of the Russian Federation by agreement with the Federation components'. However, the mechanism for reaching such an agreement is prescribed neither in the Constitution nor in other laws. ${ }^{35}$ The constitutions of Komi (article 104), Sakha (article 110), Kalmykiya (article 40), Buryatiya (article 103), Ingushetiya (article 89) recognise the right of the procurators of the republics to be appointed by the General Procurator of the Russian Federation. However, in a number of other republican constitutions, this right of appointment is given to the republican parliaments (e.g., Bashkortostan, Chechnya, Tatarstan and Tyva).

\section{Appointment of heads of other regional branches of federal ministries}

A major weapon in the hands of regional executives has been their control over the appointment of the heads of the federal bureaucracies situated in their territory. Although article 77(2) of the Russian Constitution states that there 'is a unified system of executive power' in the Russian Federation, and article 78(1) grants federal bodies the right to appoint their own territorial bodies and 'the relevant officials', republican constitutions (and some regional charters) state that such powers of appointment come under the sole jurisdiction of the federal subjects.

There are approximately forty to fifty branches of federal bureaucracies in each region. These include: power-wielding structures (the Federal Security Service and the Ministry of Internal Affairs); economic structures (agencies of the State Property Committee, the Customs Service and the Employment Service, and enterprises under federal jurisdiction); and oversight agencies (sanitary and epidemiological supervision, the tax police, the tax inspectorate, the Ministry of Finance's Oversight and Auditing Administration). ${ }^{36}$ And by 2000 there were currently about 450,000 members of federal bureaucracies working in the regions ${ }^{37}$ As we discuss in chapter 8 it is one of the main aims of the Putin regime to wrest back control of these appointments from regional executives.

\section{Bilateral agreements and the development of an asymmetrical federation}

As noted above, articles 11 and 78 of the Russian Constitution left open the door for the federal government and federal subjects to engage in 
bilateral treaties. Over the period 1994 to 1998, forty-six such treaties were signed which rapidly undermined the authority of the federal Constitution as the primary basis of federal relations. These bilateral accords often gave the local signatories substantial rights over the disposition of natural resources on their territory, special tax concessions and other economic and political privileges. Special and often secretive agreements attached to the bilateral treaties, have in addition, granted the republics the right to appoint federal officials in their territories, conduct their own independent relations with foreign states, set up their own national banks, and create their own political and administrative organs. ${ }^{38}$ In many instances the bilateral treaties actually legitimised those extra-constitutional powers which the republics had unilaterally proclaimed in their republican constitutions. Most of the treaties were limited to a set period of between two and five years. ${ }^{39}$

In Tatarstan and Bashkortostan, bilateral agreements have led to such profitable industries as petroleum extraction, petroleum refining and power generation being removed from the centre's jurisdiction and handed over to local control and ownership. Tax concessions and increased federal subsidies are a central feature of many of the bilateral agreements. Over the period 1991 to 1993, Tatarstan, Bashkortostan and Sakha practically stopped transferring payments from taxes to the centre. Fiscal relations were of a confederative nature. There was a 'war of laws' under the slogan, 'if you do not fund us we will not send you taxes'. ${ }^{40}$ According to Lavrov, outright tax losses to the Federation caused by just four special budgetary deals with the republics of Kareliya, Tatarstan, Bashkortostan and Sakha, totalled at least 2 trillion roubles, or 2.3 per cent of the federal budget's revenues in 1994. ${ }^{41}$ And other funds flowed into these republics from the profits of the oil industry (Bashkortostan and Tatarstan).

In June 1995 Sakha signed a treaty with Moscow which gave the republic ownership of 26 per cent of its diamond output, 30 per cent of its gold output, and a slightly smaller percentage of its oil and gas reserves. ${ }^{42}$ The treaty also included a section on the division of powers between the two governments and 15 other agreements dealing with a variety of issues, such as 'economic control, budget relations, the mining industry, the fuel and energy industry, the northern sea route, external relations, agriculture, communications, customs, immigration, roads, education, environment and natural resources, and federal development funds' ${ }^{43}$ In 1995 Sakha received the colossal sum of 1.3 milliard US dollars for the sale of its diamonds. A sum which was not less than the official budget income of the republic. ${ }^{44}$

In 1996 the bilateral treaties were widened to include oblasts and krais. In its bilateral treaty with the federal government, Orenburg oblast gained the status of a free economic zone, a lowering of its tax quotas, 
and financial control over 20 per cent of revenues accruing from oil and gas production in the region. ${ }^{45}$ The granting of such special economic privileges to a select group of regions has done much to undermine 'fiscal federalism' in Russia (see chapter 5). Instead of reasserting fiscal control over wayward republics and regions, the federal government seemed to go out of its way to sign special treaties with them, thereby giving legal sanction to a host of unconstitutional financial and political transactions carried out by the regions.

\section{Chronology of treaties}

The first step on this path to an 'asymmetrical federation' was the landmark treaty signed with the republic of Tatarstan on February 15, 1994. To all intents and purposes this treaty created a 'state within a state' and came as close as one could possible come to legitimising Tatarstan's own Constitution and those provisions which gave Tatarstan sovereignty over its economic and political affairs, including foreign trade and areas of foreign policy. Attached to the treaty was a package of 12 agreements signed between the governments of Russia and Tatarstan regulating relations in the spheres of trade, property, budget, finance, the banking system, the military, the military industrial complex, customs, foreign-economic ties, higher education, ecology and the coordination of the legal and security services. Undoubtedly, one of the major reasons for the treaty was to thwart the further growth of nationalist sentiment in the republic and to prevent the secession of Tatarstan from the Federation. Yeltsin admits the treaty was vitally important in that it, 'forestalled the danger of a split in the Federation' (see chapter 4). ${ }^{46}$ Other agreements were followed up in 1994 with the republics of Kabardino-Balkariya and Bashkortostan, and in 1995 four such treaties were signed with the republics of Buryatiya, North Ossetiya, Udmurtiya and Sakha.

Political factors played a major role in determining who were to be the lucky beneficiaries. In many cases such treaties were signed on the eve of parliamentary and presidential elections and were clearly part of a package to bribe the regions into submission and win over their political support for the President. Yeltsin was also able to capitalise on the fears of regional elites who believed that if the communists or the nationalists came to power they would bring a halt to the treaties. ${ }^{47}$

In 1996 there were no less than nineteen such treaties, eighteen of which were signed in the run-up to the presidential elections, including the first agreement with a non-ethnic republic which was signed by Sverdlovsk oblast on January 12. Sverdlovsk benefited from the timing of the treaty. Yeltsin's popularity rating in the country was at an all time low, and there were fears in the presidential camp that the Communists would follow up their success in the 1995 Duma elections with victory in the forth- 
coming summer presidential elections. The bilateral treaty signed with Sverdlovsk legitimised many of the demands made by the region in 1993 when it unilaterally elevated its status to that of a republic (the Urals Republic). Thus, under the provisions of the Treaty the region was granted the right to form its own civil service and the governor was given the power to approve the appointment and dismissal of all federal posts in the region. ${ }^{48}$ And as Stoner-Weiss notes, in article 8 of the bilateral treaty, the region was even given powers 'to suspend the normative acts of ministries and departments of the federal government ${ }^{\prime}{ }^{49}$ In 1997 there were a further fourteen agreements.

Those treaties that were adopted first (at a time of federal weakness), were generally more generous, granting the signatories a significant number of economic and political privileges that were denied to later signatories. Thus, for example, 'In October 1996 representatives from 6 black earth regions asked the Duma to pass a law defining the legislative and executive rights of federal subjects. Their complaint was that "those who came first earned more rights"'.50 In February 1998 the governor of Saratov Oblast, Dmitrii Ayatskov, requested that the bilateral treaty which his region had signed with the Federal Government the year before, be renegotiated, as it was too restrictive. ${ }^{51}$ One gets the idea of an endless cycle of negotiations and renegotiations gradually destroying any vestiges of constitutionalism leading the country inevitabily and inexorably from a 'treaty' federation to a 'contractual' federation. In total forty-six bilateral treaties were signed by the summer of 1998, the last with Moscow city, which came into operation on June $16 .{ }^{52}$ Paradoxically, the final treaty with Moscow was signed before the adoption of a key presidential decree in June 1999 which was designed to bring the treaties into line with the Constitution and to tighten up on the procedures by which the treaties were drawn up and implemented. ${ }^{53}$

\section{Legal and constitutional basis of bilateral treaties}

The legal basis for the treaties is firmly stated in the Constitution in articles 11 and $78^{54}$ and also in a Presidential Decree of March 12, 1996. In article 78 it clearly states that federal subjects of executive power may give up some of their powers to executive bodies of subjects of the federation as long as these do not conflict with the constitution and federal laws. Article 11 states that: 'the delimitation of areas of responsibility and powers - between bodies of the state power of the Russian Federation and bodies of state power of the components of the Russian Federation is effected by the present constitution, and the Federation treaty, and other treaties concerning the delimitation of areas of responsibility and powers'.

A special commission was set up by presidential decree on July 12, 1994 for preparing treaties, and according to the head of the commission 'all 
the treaties scrupulously followed uniform rules'.$^{55}$ However, it would appear that in reality there were many problems with regulating the treaties. Thus, Yeltsin was forced to enact a special decree on the regulation of the treaties in 1996. ${ }^{56}$ According to this decree the treaties (and accompanying agreements): (1) must not violate the Russian Constitution; (2) cannot change the status of a subject of the Federation; (3) cannot add to or change what is enumerated in articles 71 and 72 of the Constitution; and (4) must respect the supremacy of the Constitution. ${ }^{57}$

But, as we illustrate below, these provisions have simply been ignored. As Umnova demonstrates, the treaties have significantly widened the number of areas coming under joint jurisdiction as stipulated in article 72, 'In Tatarstan there were 17 new spheres, in Bashkortostan and Sakha 11, in Kabardino-Balkariya 8, North Osetiya 14, Buryatiya 3, Sverdlovsk Oblast 8, Kaliningrad Oblast 11, and Udmurtiya $11^{\prime} .^{.8}$

Thus, for example, the following areas were transferred from the exclusive authority of the federal authorities to joint jurisdiction: state defence (Tatarstan, Bashkortostan, Kabardino-Balkariya, North Osetiya); introduction of a state of emergency (Kabardino-Balkariya); conversion of defence industries to domestic production (Tatarstan, Bashkortostan, North Osetiya, Udmurtiya, Sverdlovsk and Orenburg oblasts); coordinating of military production complex (Tatarstan and Bashkortostan); management of the defence industry (Sverdlovsk oblast, Udmurtiya); the citing of military forces (Bashkortostan); arms sales (Tatarstan); coordination of budget finance, money-credit and pricing policy and the administration of public energy, transport and communications (Tatarstan, North Osetiya, Kabardino-Balkariya). ${ }^{59}$

In other cases constitutional powers exclusively reserved for the Russian federation government were transferred to the sole jurisdiction of federal subjects; international relations (Tatarstan); national banks (Tatarstan, Bashkortostan); republican citizenship (Tatarstan, ${ }^{60}$ KabardinoBalkariya, Bashkortostan ${ }^{61}$ ); the right to appoint or approve nominations for regional representatives of federal agencies, police, procuracy, judges, treasury, tax and others (Bashkortostan, Tatarstan Sverdlovsk, and many others). Thus, for example, according to the bilateral treaty signed between Ulyanovsk and the federal government, 'the heads of the tax inspectorate, treasury, police and other offices were appointed with the agreement of the oblast authorities' ${ }^{62}$

A long awaited law to regulate bilateral treaties was finally adopted by the State Duma on June 30, 1999. ${ }^{63}$ The law 'reinforced the supremacy of federal laws and the Constitution in the legal hierarchy, categorically stated the principles of glasnost in treaty promulgation, and gave the regions three years to bring existing treaties into conformity with federal law' ${ }^{64}$ However, the law came too late as no more treaties were signed after June 1998. And, it would appear to have made little impact. As we 
discuss in chapter 8 , progress in bringing bilateral treaties into line with the Constitution has been so slow that President Putin has been forced to set up yet another special commission to re-examine this whole issue.

\section{Conclusions: bilateral treaties and the federal Constitution}

As Khakimov notes, there are two basic approaches to federalism in Russia: (1) constitutional-treaty, when the centre defines the course of all the processes and delegates powers to the regions, and (2) treatyconstitutional, when relations are constructed from below up through the voluntary delegation of powers from subjects to the centre.

The supporters of the constitutional-treaty form of federalism argue that the sovereignisation of the republics on the Tatarstan model will lead to the collapse of Russia. Thus, they argue for strict controls from the centre over the subjects. Bilateral treaties according to them are simply anomalies and provincial documents which have hindered the development of a unitary state. The war with Chechnya is seen as a positive development to keep the ethnic republics in check (see chapter 4).

Those who support a treaty-constitutional federation do not consider Russia a true federation but insist on forming relations with the centre according to the model 'from below-above' through the voluntary delegation of powers with the help of bilateral treaties. Sovereignty is established on a legal basis allowing the subjects of the federation self-determination. If the first variant insists that the constitutions of the republics must correspond with that of the federal Constitution then the second variant argues the reverse, that the federal Constitution must conform to the constitutions of the republics, and that the centre must be placed under the control of the subjects. The source of power in a democracy is the people, therefore the functions of central organs must be defined by the subjects of the federation. ${ }^{65}$ Tatarstan and Bashkortorstan have been vigorous champions of the latter model.

For other scholars the bilateral treaties have played a positive role in preventing the disintegration of the federation (see chapter 4). Thus, Hughes argues that, 'the empowerment of asymmetric federalism' in Russia, 'has been the key factor in the successful management of separatist and regionalist challenges, and is the principal factor explaining its survivability as a federation'. ${ }^{66}$

The treaties have also been defended on the grounds that they allow the centre to engage in a more responsive, flexible, and democratic way to the local needs of Russia's highly diverse subjects. Furthermore, as Hughes argues, 'by decentralising power over a wide range of policy domains the treaties have acted as a counterweight to the strongly centralist state tradition in Russia', engineering 'a new institutional structure for the accommodation of Russia's plural society ${ }^{\prime 67}$ Supporters of such 
'treaty based' federalism also often refer to the Spanish example of 'foralistic federalism' to support their case. 'Foralistic federalism' was the term given to the negotiated charters drawn up between the king and the provinces in medieval Spain. As Elazar notes, in modern day Spain, bilateral agreements are authorized and adopted 'through a complex process involving the consent of the national and regional parliaments' and the 'agreements are tailored to meet the specific constitutional needs of each federal subject' ${ }^{68}{ }^{6}$ Thus, as Smith notes, developments in Russia demonstrate that federalisation may involve 'a post-constitutional process of reaching important agreements as much as it may rely on an original compact'. ${ }^{69}$

However, I would agree with those critics who argue that the treaties have fundamentally weakened the Constitution and the rule of law in Russia. Whilst the Constitution does allow for some flexibility, it may be argued that such treaties have fatally undermined its authority. The treaties make a mockery of article 5 of the federal Constitution which states that the relations between the centre and all the subjects are equal. Moreover, it is clear that the bilateral treaties have, in all but name, elevated a select number of oblasts to the status of de facto republics.

Furthermore, it is also important to note that the treaties were never legitimised by the national parliament (Duma or Federation Council) nor by the legislative bodies of the subjects. These were agreements between executive bodies of power - signed usually by either the President or the Prime Minister and the chief executive of the regions. In April 1997, the Federation Council vetoed legislation which would have given the Duma such powers. Also we should take note of the complete silence of the constitutional court as regards the constitutionality of the bilateral treaties. Not a single treaty was brought before the court for examination. Clearly, such sensitive areas were kept out of its purview. The court, since its reincarnation in 1995, does not have the power to initiate hearings but must have cases brought before it.

In conclusion, the bilateral treaties have led to a situation, whereby some poor regions are totally dependent on the centre and no real federal relations exist whilst a second stronger group has the trappings of federalism, and finally the most powerful autonomous entities, such as Tatarstan, coexist with Moscow as part of an exclusive club of confederative states. ${ }^{70}$ Moreover, the treaties have increased the already high level of 'constitutional asymmetry' operating in the Federation.

\section{Appendix 3.1 Article 71 of the December 1993 Russian Constitution}

The following fall within the jurisdiction of the Russian Federation:

a) adoption and amendment of the constitution of the Russian Federation and federal laws, and the monitoring of compliance with them; 
b) the federative system and territory of the Russian Federation;

c) the regulation and protection of human and civil rights and freedoms; citizenship of the Russian Federation; the regulation and protection of the rights of national minorities;

d) the establishment of a system of federal bodies of legislative, executive, and judicial power, the procedure for their organization and activity; the formation of federal bodies of state power;

e) federal state property and the management thereof;

f) the establishment of the fundamentals of federal policy and federal programmes in the sphere of the state, economic, ecological, social, cultural and national development of the Russian Federation;

g) the establishment of the legal foundations of the single market; financial, currency, credit and customs regulation, monetary emission and the foundations of pricing policy; federal economic services, including federal banks;

h) the federal budget; federal taxes and duties; federal regional development funds;

i) federal power systems, nuclear power generation, fissile materials; federal transport, railways, information and communications; activity in space;

j) the Russian Federation's foreign policy and international relations and the Russian Federation's international treaties; issues of war and peace;

k) the Russian Federation's foreign economic relations;

1) defence and security; defence production; the determination of the procedure for the sale and purchase of weapons, ammunition, military hardware and other military property; the production of toxic substances, narcotic substances and the procedures for their use;

$\mathrm{m}$ ) the determination of the status and protection of the state border, territorial seas, airspace, the exclusive economic zone and the continental shelf of the Russian Federation;

n) the judicial system; the procurator's office; legislation in the field of criminal, criminal-procedure and criminal-executive law; amnesty and the granting of pardons; legislation in the field of civil law, the law of civil procedure and the law of arbitration procedure; the legal regulation of intellectual property;

o) federal law relating to the conflict of laws;

p) the meterological service, standards and standard weights and measurements, the metric system and measurement of time; geodesy and cartography; geographic names; official statistical records and accounting;

q) state awards and honorary titles of the Russian Federation;

r) the federal civil service. ${ }^{71}$

\section{Appendix 3.2 Article 72 of the December 1993 Russian Constitution}

The following fall within the joint jurisdiction of the Russian Federation and the components of the Russian Federation: 
a) the guaranteeing that the constitutions and laws of republics, and the charters, laws and other normative legal acts of krais, oblasts, cities of federal significance, the autonomous oblasts and autonomous okrugs accord with the constitution of the Russian Federation and federal laws;

b) the protection of human and civil rights and freedoms; the protection of the rights of national minorities; the guaranteeing of legality, law and order and public safety; the arrangements relating to border zones;

c) issues relating to the ownership, use and disposal of land, mineral resources, water and other natural resources;

d) the delimitation of state property;

e) the use of the natural environment; environmental protection and the guaranteeing of ecological safety; natural sites under special protection; the protection of historical and cultural monuments;

f) general issues of nurture, education and science, culture, physical fitness and sport;

g) the coordination of questions of public health; the protection of the family, mothers, fathers and children; social protection, including social security;

h) the implementation of measures for combating catastrophes, natural disasters and epidemics and the elimination of their consequences;

i) the establishment of general principles of taxation and levying of duties in the Russian Federation;

j) administrative, administrative-procedural, labour, family, housing, land, water, and forestry legislation, and legislation on mineral resources and on environmental protection;

k) personnel of judicial and law-enforcement bodies; attorneys and notaries;

1) protection of the primordial habitat and traditional way of life of numerically small ethnic communities;

m) the establishment of the general principles for the organization of a system of bodies of state power and local self-government;

n) the coordination of the international and foreign economic relations of components of the Russian Federation and the fulfilment of the Russian Federation's international treaties. ${ }^{72}$

\section{Notes}

1 R. Taras, Consolidating Democracy in Poland (Boulder, Colorado: Westview Press, 1995), p. 170.

2 J. M. Maravall and T. di Tella, 'Democratic institutions', in A. Prezeworski (ed.), Sustainable Democracy (Cambridge: Cambridge University Press, 1995), p. 50.

3 Ibid.

4 A. Stepan, 'Russian federalism in comparative perspective', Post-Soviet Affairs, 16:2 (2000), 148.

5 A. Zverev, 'Qualified sovereignty: the Tatarstan model for resolving conflicting loyalties', in M. Waller, B. Coppieters and A. Malashenko, Conflicting 
Loyalties and the State in Post-Soviet Russia and Eurasia (London: Frank Cass, 1998), p. 131.

6 See, C. Ross, 'Federalism and regional politics', in M. Bowker and C. Ross (eds), Russia after the Cold War (Harlow: Pearson Education, 2000); C. Ross, 'The republicanisation of Russia - 2: federalism and democratisation in transition', in C. Pierson and S. Tormey (eds), Politics at the edge (London: Macmillan, 2000), and R. Sakwa, 'The republicanisation of Russia -1 ', in the same collection.

7 G. W. Lapidus and E. W. Walker, 'Nationalism, regionalism and federalism', in G. W. Lapidus (ed.), The New Russia: Troubled Transformation (Boulder; San Francisco; Oxford: Westview Press, 1995), p. 102.

8 For example in the Republic of Ingushetiya turnout was just 46.0 per cent, Khakasiya (45.6), Komi (47.2), Marii-El (46.8), Tatarstan (13.4) and Udmurtiya (44.2).

9 S. White, S. Rose and M. McAllister (eds), How Russia Votes (New Jersey: Chatam House, 1997), p. 100.

10 R. L. Watts, Comparing Federal Systems (Montreal and Kingston: McGill-Queen's University Press, 2nd edn, 1999), pp. 92-5.

11 D. Kempton, 'Russian federalism: continuing myth or political salvation', Demokratizatsiya, 9:2 (Spring 2001), 217.

12 Watts, Comparing Federal Systems, pp. 95-6.

13 A. Stepan, 'Federalism and democracy: beyond the U.S. Model', Journal of Democracy, 10:4 (1999), 24.

14 Watts, Comparing Federal Systems, p. 96.

15 Kempton, 'Russian federalism', 215.

16 Stepan, 'Federalism and democracy', 27.

17 Ibid.

18 The upper house meets only for two days every three weeks.

19 O. Oracheva, 'Democracy and federalism in post-communist Russia', paper presented at the conference, The Fall of Communism in Europe: Ten Years On, May 14-17, 2001, The Hebrew University of Jerusalem, p. 7.

20 Kempton, 'Russian federalism', 219.

21 L. M. Karapetyan, Federalizm i Prava Narodov (Moscow: PRIOR, 1999), p. 49.

22 Forty-four articles of the Bashkortostan constitution contradicted the Russian Constitution.

23 I. A. Umnova, Konstitutsionnye Osnovy Sovremennovo Rossiiskovo Federalizma (Moscow: DELO, 1998), p. 106.

24 S. V. Alekseev, V. A. Kalamanov and A. G. Chernenko, Ideologicheskie Orientiry Rossii, Volume 2 (Moscow: Kniga i Biznes, 1998), p. 392.

25 Ibid., p. 108.

26 Rabinowich, EWI Russian Regional Report (December 2000).

27 Alekseev et al., Ideologicheskie Orientiry, p. 107.

28 Karapetyan, Federalizm i Prava, p. 48.

29 Ibid., p. 47. Article 89 also declares that the President of the Russian Federation, 'decides questions of citizenship of the Russian Federation'. The 'Law on Citizenship of the Russian Federation' which was adopted on 28 November 1991 (and was amended in 1993 and 1995) also regulates such questions. There are also republican laws on citizenship. Article 2 of the Law on Citizenship of the Russian Federation states that a citizen of the Russian Federation 
permanently residing in the territory of a republic is at the same time a citizen of that republic. And article 23 further notes that termination of citizenship of the Russian Federation also means termination of such republican citizenship. For Karapetyan the fact that a citizen has both republican and Russian citizenship does not equal dual citizenship. Rather, it signifies a legal relationship with the federal state and with the republic, in the framework of a single common and indivisible citizenship. For Karapetyan, there is no provision in law for a citizen of a republic not holding at the same time citizenship of the Russian Federation (see Karapetyan, Federalizm i Prava, p. 48).

30 Watts, Comparing Federal, p. 100.

31 Kempton, 'Russian federalism', 212.

32 Ibid.

33 Adygeya, Bashkortostan, Buryatiya, Dagestan, Kabardino-Balkariya, Kareliya, Komi, Marii El, Sakha, Tatarstan, Sverdlovsk Oblast and the city of St Petersburg. See A. Trochev, 'The constitutional courts of Russia's regions: an overview', IEW, Russian Regional Report, 6:44 (December 12, 2001), 16.

34 Ibid., p. 21.

35 I. Mikhailovskaya, 'The procuracy and its problems', East-European Constitutional Review, 8:1-2 (Winter-Spring 1999), 4.

36 M. Sergeeva, Kommersant Daily (26 October 1996), 1., translated in CDPSP, 48:43 (November 20, 1996), 1.

37 L. Smirnyagin, 'Federalizm po Putiny ili Putin po federalizmu (zheleznoi pyatoi)', Carnegie Briefing Papers, 3:3 (March 2001), 2.

38 See, Umnova, Konstitutsionnye Osnovy, pp. 108-14.

39 K. Stoner-Weiss, 'Central weakness and provincial autonomy: observations on the devolution process in Russia', Post-Soviet Affairs, 15:1 (1999), 91.

40 A. Lavrov, 'Asimmetriya byudzhetnovo ustroistva Rossii: problemy i resheniya', in A. Zakharov (ed.), Asimmetrichnost' Federatsii (Moscow: MONF, 1997), pp. 99-122, 113.

41 A. M. Lavrov, 'Russian budget federalism: first steps, first results', Sevodnya (June 7, 1995). Translated in CDPSP, 47:23 (1995), 3.

42 V. Emelyanenko, 'Russia: waiting for IOUs', Moskovskie Novosti, 44 (June-July 1995), 2. Translated in CDPSP, 47:26, 1995, pp. 14-15.

43 John F. Young, 'The republic of Sakha and republic building', in K. Matsuzato (ed.), Regions: A Prism to View the Slavic-Eurasion World (Sapporo, Japan: Hokkaido University, 2000), p. 186.

44 Lavrov, 'Russian budget federalism', p. 3.

45 Orenburg, December 1995, p. 116, December 10-17, 1995.

$46 \mathrm{~B}$. Yeltsin, 'The might of the state grows through the independence of the regions', Rossiiskie Vesti (November 1, 1997). Translated in CDPSP, $49: 44$ (1997), 14.

47 M. Fillipov and O. Shvetsova, 'Assymetrical bilateral bargaining in the new Russian federation: a path-dependence explanation', Communist and PostCommunist Studies, 32 (1999), 73.

48 EWI Russian Regional Report, 5:24 (June 21, 2000), 6.

49 K. Stoner-Weiss, 'Central weakness and provincial autonomy', 93.

50 Fillipov and Shvetsova, 'Asymmetric bilateral bargaining', 73.

51 Ibid., 74. 
52 A. Kuzmin, N. Petrov and A. Titov, 'Russian federalism: the view from the centre and from the regions', unpublished paper delivered to the Conference, Contemporary Russian Federalism: Problems and Perspectives, Carnegie Centre, Moscow, December 1997, pp. 9-10.

53 See note 63 .

54 Thus article 78(2) states, 'The federal bodies of executive power, by agreement with the bodies of executive power of the components of the Russian Federation can transfer to them the implementation of some of their powers provided that this does not conflict with the constitution of the Russian Federation and federal laws'. And article 78(3) notes, 'By agreement with the federal bodies of executive power the bodies of executive power of the components of the Russian Federation can transfer to them the implementation of some of their powers'.

55 T. Sadkovskaya, Rossiskiye vesti (January 23, 1998), p. 3.

56 Presidential Decree Number 370, March 12, 1996 (with changes on November 25, 1996); ‘Ob Utverzhdenii Polozheniia O Poriadke Raboty Po Razgranicheniyu Predmetov Vedeniya i Polnomochii Mezhdu Federal'nymi Organami Gosudarstvennoi Vlasti i Organami Gosudarsvennoi Vlasti Sub'ektov Rossiiskoi Federatsii i O Vzaimnoi Peredache Osushchestvleniya Chasti Svoikh Polnomochii Federal'nymi Organami Ispolnitel'noi Vlasti i Organami Ispolnitel'noi Vlasti Sub'ektov Rossiiskoi Federatsii', Sobranie Zakonodatel'stva Rossiiskoi Federatsii, 12 (1996), 1058.

57 K. Stoner Weiss, 'Central weakness and provincial', 91. Yeltsin's decree of Ocober 5, 1995 also makes the same point and notes that subjects must remove any provisions in their laws, charters or constitutions which infringe the Russian Constitution.

58 Umnova, Konstitutsionnye Osnovy, p. 112.

59 Ibid.

60 In Tatarstan the bilateral treaty further muddies the waters by providing a number of contradictory statements on citizenship. Thus, article 4 conforms with article 71 of the Russian Constitution, stating that this is a federal matter, article 3 places citizenship under joint jurisdiction, and article 2 grants such questions to republican jurisdiction.

61 Stoner-Weiss, 'Central weakness and provincial', p. 92.

62 S. Gogin, IEWS, Russian Regional Report, 5:3 (January 26, 2000), 7.

63 'O Printsipakh i Poryadke Razgranicheniya Predmetov Vedeniya i Polnomochii Mezhdu Organami Gosudarstvennoi Vlasti Rossiiskoi Federatsii i Organami Gosudarstvennoi Vlasti Sub'ektov Rossiiskoi Federatsii', adopted by the State Duma, 4 June, 1999 and ratified by the President on June 24, 1999. Rossiiskaya Gazeta (June 30, 1999), 3.

64 J. Kahn, 'What is the new Russian federalism?', in A. Brown (ed.), Contemporary Russian Politics: A Reader (Oxford: Oxford University Press, 2001), p. 381.

65 R. Khakimov, 'Asimmetrichnost' Rossiiskoi Federatsii: vzglyad iz Tatarstana', 72-3.

66 'Institutional design and political stability: asymmetric federalism in Russia's state of transition', paper delivered to the ESRC Research Seminar, Regional Transformations in Russia, London School of Economics and Political Science, October 21, 1998, p. 3. 
67 J. Hughes, 'From federalisation to recentralisation', in S. White, A. Pravda and Z. Gitelman (eds), Developments in Russian Politics - 5 (Basingstoke: Palgrave, 2001), p. 145.

68 D. Elazar, Exploring Federalism (Tuscaloosa and London: University of Alabama Press, 1987), pp. 59, 165.

69 G. Smith, The Post-Soviet States: Mapping the Politics of Transition (London; Sydney; Auckland: Arnold, 1999), p. 140.

70 V. Shpak, Kommersant Daily (January 20, 1998), p. 4.

71 M. V. Baglai, Konstitutsionnoe Pravo Rossiiskoi Federatsii (Moscow: Norma, 2001), pp. 313-17.

72 Ibid. 